$\mathrm{CrO}_{4}^{=}$. In bichromated gelatine films both ions absorb light of short wave-length, the absorption of $\mathrm{HCrO}_{4}^{-}$being greater than that of $\mathrm{CrO}_{2}^{=}$over a range of $400-560 \mathrm{~m} \mu$, coming to a maximum at approximately $440 \mathrm{~m} \mu$. The brown product of the oxidation, generally assumed to be $\mathrm{CrO}_{2}$, also absorbs actinic light.

It is possible to explain the increase in contrast in view of the above facts. Gelatine films sensitised in a solution of high hydrogen ion concentration will be more sensitive to light than those sensitised in solutions containing ammonia, and will therefore attain a relatively higher density with short exposures. They do not, however, give relatively higher density values with long exposure on account of the screening effect of the $\mathrm{CrO}_{2}$, which forms, as it were, a filter between the light and the unexposed portions of the film, the formation of $\mathrm{CrO}_{2}$ being more rapid when the concentration of $\mathrm{HCrO}_{4}^{-}$is high.

It is hoped that this work, which is proceeding, will further elucidate the theory of the photo-activity of bichromated colloids, and that it will have some bearing on workshop practice. We should be interested to hear from anyone who may be following investigations on similar lines.

\section{H. Mrlls Cartwright.}

6, Bolt Court,

$$
\begin{aligned}
& \text { Fleet Street, E.C.4. } \\
& \text { Sept. 21. } \\
& \text { ' J. Chem. Soc., } 2031 ; 1932 .
\end{aligned}
$$

\title{
Decomposition of Specific Bacterial Polysaccharides by a Species of Myxobacterium
}

DURING the course of work carried out to determine the nature of the carbohydrate groupings that are associated with immunological specificity in bacterial antigens, the action of certain micro-organisms on the purified specific polysaccharide of $B$. dysenterioe, Shiga, was investigated.

We have isolated a micro-organism from a specimen of decayed vegetable debris which rapidly decomposes the specific polysaccharide ${ }^{1},[\alpha]_{5461}^{18^{\circ}}+110^{\circ}$, of Shiga's bacillus. The isolation was effected by the use of a synthetic mineral medium described by Dubos and Avery ${ }^{2}$, in which the only source of carbon is the specific polysaccharide. In this medium the organism grows poorly, but we have found that the addition of a small amount of an aqueous extract of rabbit fæces or the presence of culture-filtrates of certain other micro-organisms increases both the rate and the density of growth.

The morphology of the organism when studied on the special mineral medium to which agar has been added, appears to be that of a typical Myxococcus, Thaxter ${ }^{3}$, but as the most suitable conditions for growth have not so far been ascertained, it is not possible to state whether typical cyst formation occurs.

The action of the organism on the specific polysaccharide of other bacterial species has also been examined. The accompanying table summarises the results obtained when $0 \cdot 10$ c.c. of an actively growing culture of the Myxobacterium was implanted in 3 c.c. of the synthetic mineral medium to which a bacterial polysaccharide had been added to make a final concentration of 0.005 per cent. The cultures, after incubation for 2 or 7 days at $37^{\circ} \mathrm{C}$., were tested with the homologous immune-serum. The

specific polysaccharides of $B$. dysenterice, Shiga $B$. dysenterice, Flexner Y, Pneumococcus (Type II) ${ }^{4}$ and the tubercle bacillus $s^{5,6}$ were attacked and their

\begin{tabular}{|c|c|c|c|}
\hline \multirow{2}{*}{$\begin{array}{l}\text { Specific polysaccharide } \\
\text { isolated from }\end{array}$} & \multicolumn{3}{|c|}{$\begin{array}{l}\text { Precipitation with the homologous } \\
\text { immun --serum }\end{array}$} \\
\hline & $\begin{array}{l}\text { Control } \\
\text { (uninoculated } \\
\text { mediums) }\end{array}$ & $\begin{array}{l}\text { After } \\
2 \text { days } \\
\text { growth }\end{array}$ & $\begin{array}{l}\text { After } \\
7 \text { days } \\
\text { growth }\end{array}$ \\
\hline $\begin{array}{l}\text { B. dysenterice, Sliga } \\
\text { B. dysenterio, Flexner } \mathrm{Y} \\
\text { Pneumn'occus (Type I) } \\
\text { Pneumocorcus (Type II) } \\
\text { Tuberile bacillus (Human) } \\
\text { B. proteus X19.' } \mathrm{O}^{\prime} \text { variant }\end{array}$ & $\begin{array}{l}h \\
m \\
h \\
h \\
h \\
m\end{array}$ & $\begin{array}{l}n \\
n \\
h \\
n \\
8 \\
m\end{array}$ & $\begin{array}{l}n \\
n \\
h \\
n \\
8 \\
m\end{array}$ \\
\hline
\end{tabular}
power to form a specific precipitate when mixed with the homologous immune-serum was destroyed.

$h$ heavy precipitate. $m$ medium precipitate. $s$ slight precipitate.

So far as we are aware, this is the first reported instance of a micro-organism which is able to attack and to destroy the immunological properties of several specific bacterial polysaccharides.

Experiments are in progress to investigate the action of the Myxobacterium on other specific bacterial polysaccharides and to isolate from cultures of it an active enzyme preparation.

\section{Serum Department, Lister Institute, Elstree, Herts.}

W. T. J. Morgan.

Bacteriological Laboratory,

Chemical Research Department, Teddington, Middlesex. Sept. 14.

1 Morgan, Brit. J. Exp. Path., 12, 62; 1931

2 Dubos and Avery, $J$. Exp. Med., 54, 51 ; 1931

3 Thaxter, Bot. Gaz., 17, 389; 1892.

- Heidelberger and A very, J. Exp. Med.. 33, 73: 1923.

5 Laidlaw and Dudley, Brit. J. Exp. Path., 6, 197 ; 1925.

${ }^{6}$ Gough, Biochem. J., 23, 248; 1932.

\section{Method for the Separation of Enzymes from their Mixtures}

Enzymes usually occur in mixtures and often associated with other inert impurities. Their purification and separation into their individual components have been accomplished largely through methods of selective adsorption and elution developed by Willstätter and his pupils.

The method to be described takes advantage of the difference in the molecular weights of enzymes, which are therefore expected to vary in their rates of diffusion and sedimentation in a centrifugal field. The experimental procedure consists in freezing about 20 c.c. of the clear enzyme extract in a centrifuge tube in a mixture of ice and salt, and centrifuging the frozen mass at about 6,000 r.p.m. for about fifteen minutes. The centrifuge tube when afterwards taken out is found to consist usually of three distinct layers which can be carefully pipetted off. The topmost layer consists of practically pure ice-cold water, containing the more easily diffusable enzyme fractions, the bottom layer represents the most concentrated fraction and mainly consists of enzymos with higher molecular or micellar weights. There is to be found, in addition to the three layers, a solid at the bottom of the centrifuge tube, representing inert impurities present in the 